KAWISTARA

VOLUME 3

No. 2, 17 Agustus 2013

Halaman 117-226

\title{
THE LEGITIMAZATION OF VIOLENCE AGAINST THE AHMADIYYA COMMUNITY IN INDONESIA
}

\author{
Torhild Breidlid \\ Program Studi Agama dan Lintas Budaya \\ Sekolah Pascasarjana Universitas Gadjah Mada \\ Email: torhildbre@hotmail.com
}

\begin{abstract}
ABSTRAK
Komunitas Ahmadiyah di Indonesia telah mengalami peningkatan pelanggaran atas kebebasan beragama mereka dalam berbagai bentuk selama sepuluh tahun terakhir. Terbukanya demokrasi pada tahun 1998 mengakibatkan keterlibatan "aktor-aktor non negara" dalam kekerasan agama. Meskipun terjadi peningkatan serangan terhadap komunitas Ahmadiyah, negara enggan untuk mencegah atau menghukum serangan agama terhadap komunitas Ahmadiyah. Tulisan ini menyatakan bahwa kekerasan terhadap Ahmadiyah berada dalam bahaya yang menjadi sah terlegitimasi.
\end{abstract}

Kata kunci: Ahmadiyah, FPI, Legitimasi Kekerasan, Patronase Negara, Desentralisasi

\section{ABSTRACT}

The Ahmadiyah community in Indonesia has experienced increasing infringement on their religious freedom in various forms during the last ten years. The opening up of democracy in 1998 resulted in the involvement of "non state actors "in religious violence. Despite increasing attacks against the Ahmadiyah community, the state has been reluctant to prevent or punish religious attacks against the Ahmadiyah community. In this article I argue that violence against the Ahmadiyah is in danger of becoming legitimate.

Key words: Ahmadiyah, FPI, Legitimatization of Violence, State Patronage, Decentralization 


\section{INTRODUCTION}

This paper discusses on multiple causes for attacks and discrimination against the Ahmadiyah community in Indonesia. Attacks are not only directed against Ahmadiyah followers, but also on their mosques and homes. It also investigates the response of the state to violence against the Ahamdiyah community. There have been numerous articles about the religious freedom of the Ahmadiyah community in Indonesia. Many of these articles have mainly focused on laws and law enforcement in Indonesia. However, this paper that attacks on the Ahmadiyah community are more complex and caused by multiple factors.

West Java is one of the hotspot for attacks on the Ahmadiyah community. This field research was conducted in West Java and use examples from West. The interviews were conducted in different Islamists in Cirebon as well as members of the Ahmadiyah community in Bekasi. It discusses on what degree the state facilitates religious attacks against the Ahmadiyah community in Indonesia. One issue is the misuse of laws and regulations as a way of discriminating against the Ahmadiyah community. The Indonesian state is about to lose control over its legitimate use of violence by allowing vigilant groups to harass the Ahmadiyah community.

It also discusses on how the attackers retain a certain degree of legitimacy of the violence they commit. There may not only be theological/ideological reasons for the attacks. Changes are unlikely to occur unless we see fundamental economic, social, political and legal reforms in Indonesia. The multiple causes on why violence against the Ahmadiyah may seem to become"legitimate" in Indonesia. It uses the definition of "legitimate" as described by Charles Tilly as "the probability that other authorities are likely to confirm the decision of a given authority (Tilly, 1985: 169-191).

\section{DISCUSSION}

\section{Ahmadiyah Community in Indonesia: Who are They?}

The Ahmadiyya movement was founded in 1889 in Kadiani, India by Mirza
Ghulam Ahmad. Ahmadiyya is normally seen as a deviant sect of Islam by mainstream Muslims. While the Ahmadiyyas consider themselves Muslims, many conventional Muslims do not consider them as such. In Indonesia, the Ahmadiyya group is divided into Ahmadiyya Muslim Community (JAI) and the smaller Lahore Ahmadiyya Movement for the Propagation of Islam (GAI). The GAI is seen as a more moderate branch of Ahmadiyya, where they see Mirza Ghulam Ahmad as a mere reformer of Islam. On the other hand JAI believes that Mirza Ghulam Ahmad himself was a Prophet, and that he was the promised Messiah and the Mahdi. To claim that Muhammad was not the last prophet is highly controversial and seen as unacceptable by mainstream and orthodox Muslims (Colbran, 2000). Within the Indonesian context, the entire Ahmadiyya movement encompasses some 400000 members.

There have been several attacks on the Ahmadiyya community in Indonesia, by non-state actors, especially by some Islamist groups. One interesting aspect is that the violence against the Ahmadiyya community is a fairly recent occurrence. The Ahmadiyyas lived relatively peacefully with their Muslim counterparts after they arrived in Indonesia in the 1920s. However, since the Independence of Indonesia in December 1949 Islamists were heavily suppressed during the two dictatorships. This changed in 1998, when Indonesia experienced increased political liberalization and transition to democracy. As a consequence, increased political space has seen a flourishing of civil society groups in Indonesia. Thus, even though most civil society groups are advocates of democracy and human rights, some groups are illiberal and have a negative attitude to the promotion of human rights. Political liberalization has thus, somewhat paradoxically, given Islamist groups leverage (Colbran, 2000).

\section{Who are the Islamists?}

Even though the Ahmadiyah community is seen as a controversial deviant sect by large segments of the population, the violence is 
nevertheless almost exclusively committed by Islamists. An Islamist is a proponent of Islamism, and Olivier Roy gives the following definition of Islamism Islamism is the brand of modern political Islamic fundamentalism that claims to re-create a true Islamic society, not simply by imposing sharia, but by establishing firstly an Islamic state through political action. Islamists see Islam not as a mere religion, but as a political ideology that should reshape all aspects of society (politics, law, economy, social justice, and foreign policy and so on (Roy, 2004: 247).

One of the most prominent groups is the Islamic Defenders Front (FPI). FPI was founded by Misbahul Anam, a Nahdatul Ulama-educated preacher, and Habib Rizieq, a habib (an Islamic preacher tracing familial descent from the Prophet Muhammad) of mixed Arab-Betawi descent. While the leadership of the FPI consists of Muslim scholars, rank members are usually poor urban youth (Wilson, 2005). The membership is increasing rapidly. By 2005 the FPI had over hundred thousand members. Since the FPI is the most prominent group, there are examples from the FPI in this apaper. Interviews were conducted with several regional Islamists groups in Cirebon, (West Java), such as Gerakan Muslim Penyelamat Akidah (Gempa), Gerakan Anti-Pemurtadan dan Anti Aliran Sesat (Gapas), Pagar Akidah (Faith Fence), and Cirebon Muslim Movement (GMC). Common to all these groups is their commitment to implementing sharia law in Indonesia and the purification of Islam.

What distinguishes these groups from other Islamist parties and Islamist organizations is their tendency to use violence. Hence, it is important to emphasize that most Islamist groups and organizations do not engage in violent activities. Even though Nahdatul Ulama is considered a conservative Islamist organization, it nevertheless condemns violent attacks on Ahmadiyahs. However, the groups that do engage in violence, legitimatize the violence by claiming to be moral agents, acting on behalf of the state which is too weak to crack down on vice and immorality. The Islamists target
Ahmadiyahs, nightclubs, brothels and liberal Muslims. The leader of Gapas, Andi Mulya argues: "Gapas just documents vice and blashemic activities and only takes action when the police fail to act" (New York Times, 2001). These Islamists have been criticized for being thugs or "criminals/preman in disguise"using simplistic religious symbols to legitimatize violence. The Islamists have nevertheless been able to make elite alliances, thus posing a security threat in Indonesia (Abuza, 2007).

\section{The Indonesian State's Response to Religious Violence The Legal Framework of Religious Freedom in Indonesia}

This section discusses on what degree laws in Indonesia facilitate or prevent violence against the Ahamdiayh community. The Constitution of Indonesia is the superior legal source in Indonesia. In the preamble of the Constitution is the Pancasila which means "five pillars" and describes the ideological foundation of Indonesia. The first pillar is the belief in the one and only God. Historically, the pillar was made as a compromise between followers of an Islamic state and seculars (Tomte, 2012). Thus, although Indonesia is not an Islamic state, it is not a secular, but a religious state. As will be discussed later in this section, the Pancasila sets the framework for the Indonesian interpretation of religious freedom. Freedom of religion is ensured in the Indonesian constitution of 1945.

After the transition to democracy in 1998, the constitution was amended and a human right chapter was included. Art. $28 \mathrm{E}$ in the human rights chapter guarantees everyone the freedom of religion. The Human Rights Act was passed in 1999 and religious freedom was ensured, similarly to that in the constitution. Indonesia ratified the International Convention on Civil and Political Rights in 2005. This means that the state has a duty to protect, fulfill and respect freedom of religion for its citizens. Religious freedom as described in art. 18 in the convention encompass both internal 
religious freedom and external religious freedom.

There are no limitations to internal religious freedom; everyone is entitled to have their own belief, or not to believe. External religious freedom encompasses freedom of worship, form religious associations, et cetera. There are certain limitations to external religious freedom but such limitations are only allowed under severe circumstances (General comments art 18, ICCPR). According to art.18 (3), limitations are only allowed if the limitation is prescribed by law, and secondly in order to protect public safety, public order, health, morals or the fundamental freedom of others. Furthermore, limitations must be proportionate to the need indicated and must not be imposed in a discriminatory manner or for discriminatory purposes. Further, if a citizen's freedom of religion is violated, he/ she has the right to an effective remedy through a court proceeding.

The normative human rights framework for the protection of religious freedom seems strong in Indonesia. However, to ensure religious freedom in Indonesia it is also important that other laws are consistent with the ICCPR and the constitution. The following will discuss on laws which were issued prior to the transition to democracy in 1998. I argue that these laws are inconsistent with religious freedom as set out in the constitution and the ICCPR.

\section{Blashemphy Law}

The blasphemy law (1965) describes the religions adhered to in Indonesia, which are: Islam, Catholicism, Protestantism, Buddhism, Hinduism and Confucianism. At the same time it claims that other religions are not prohibited in Indonesia. However, the law has been interpreted in such a way that only the six religions, including the two versions of Christianity are recognized in Indonesia. Moreover, deviant interpretations and activities of the core religious teachings are seen as blasphemous and hence prohibited. The penal code art.15.6a criminalizes defamation and misuse of one of the official religions.
In essence, the blasphemy law is there to prevent hatred and incitement to violence against religious groups. However, a law concerning the defamation of a religion may be problematic, because it may serve as an incentive for the state or non-state actors to accuse individuals for defamation of religion, just because they belong to another religion, or more precisely: deviate from one of the official religions (Colbran, 2010). Hence, the law concerning defamation of religion and penal code of 156a does not protect religious minorities from discrimination. Moreover, the laws allow religious minorities to be prosecuted for defamation, because their core religious teachings deviate from one of the "six recognized religions."

Under increasing pressure from Islamists to ban JAI (which is the main Ahmadiyah sect), the government announced in 2008 the Joint Decree Letter, which was based on the blashemy law (The joint ministeal decree, 2008). The letter declared that all Ahmadiyahs who claim to be Muslims must cease all dissemination of interpretation which is deviant from the mainstream interpretation of Islam. The Ahmadiyhas had two options; either to conform to mainstream Islam teachings or declare themselves NonMuslims. Neither of these alternatives was appealing to the Ahmadiyahs. If they did not follow these requirements, they risked being punished under the penal code 156a (Colbran, 2010). The law did not outright ban the Ahmadiyah community, but was more of a warning to the Ahmadiyah`s. However, as seen in the next sections the joint decree has been unlawfully used by local governments to issue similarly decrees in their local communities.

In 2009-2010 the blasphemy law was challenged at the constitutional court in Indonesia for being unconstitutional. The petitioners claimed that "the blasphemy law's" prohibition of religious activities which deviate from the core teachings of a religion violated religious freedom set out in the constitution. They further claimed that the law violated the internal dimension of religion, since 
it prohibits deviant interpretation of core religious teachings. However, despite strong human rights arguments against the law, the court declared it constitutional (though with recommendations to make it clearer and ensure non-discriminatory law enforcement). The court emphasized the importance of maintaining public order and ensuring religious harmony. They argued that deviant religious activities and defamation might provoke and disturb public order and create religious tensions. Hence, the law was necessary in order to prevent violence and ensure religious harmony, which is an important feature of Javanese culture (Tomte, 2012).

The Indonesian interpretation of religious freedom was evident in the court ruling. The court referred to Pancasila, and claimed that deviant activities leading people away from God could not be accepted. They also emphasized the "rights of others" which included the right of others or communities not to be insulted from deviant religious activities. Hence a community right not to be offended was superior to an individual's freedom of religion. Some elements of the court ruling seems problematic and unjustifiable from a human rights perspective.

First of all, as described, Indonesia is a state party to the ICCPR and is obliged to follow its obligations. The ICCPR mentions the communitarian aspect of freedom of religion, but not that it is superior to the individual aspect of religious freedom. Hence, the court ruling did not meet its international human rights obligations, which is a case of concern. The fact that the law was necessary in order to avoid religious violence is also highly questionable. Quite the contrary, the law may give violent actors more legitimate reasons to attack deviant minority groups such as the Ahmadiyahs. It is evident, especially after the Joint Decree Letter which is based on the blasphemy law that violence against the Ahmadiya has has increased (Setara Institute, 2009).

Hence, through the blashemy law and the Joint Decree Letter of 2008 the state facilitates indirectly and directly violence against the
Ahmadiyah community. Indirectly through laws and regulations which do not fully protect the Ahmadiyahs in line with other "recognized" religions, and directly through the Joint Letter Decree 2008 which stimulated increased discrimination and attacks on the Ahmadiyah community. Laws and decrees is one of the many factors which contribute to increasing "legitimization of violence" against the Ahmadiyah community.

\section{Democratization of Legitimate Use of Violence in the Post New Order/ Reformasi}

This section explores on the Indonesian government response to violence against the Ahmadiyah community. It argues that the fragmented Indonesian state is giving vigilant groups such as Islamists' legitimacy in using violence. According to Max Weber (1919), it is only the state that should have the legitimate power to use violence. Hence, other non- state actors' use of violence is not legitimate. According to Ian Wilson, FPI and other Islamist violent actions seem nevertheless to have some legitimacy in Indonesia and thus threatens Weber' $s$ perception on the state as the only holding of legitimate power of violence (Wilson, 2005).

The reason for this is related to Indonesia's transition from an authoritarian to a democratic, but fragmented state. As mentioned there have been several attacks on Ahmadiyya and attacks on their mosque. The state, some local governments and the police have been criticized for not being able or willing to prevent or punish attacks from Islamists. In many instances the police have been at the crime scene, but not done anything in preventing attacks. Punishments for the attacks have been lenient and very low.The inability or unwillingness of the state to systematically crack down on the vigilant groups has provided them with legitimacy.Wilson argues that the reasons why these groups seem to be given impunity are complex.

First of all, the vigilant groups justify their actions by claiming to act on behalf of a 
weak and fragmented state. This is because the state is not able to provide adequate services such as protection, justice and employment. Moreover, the vigilant groups are justifying the violence through religious symbolism and by propagating morality in society. This has given these groups more legitimacy, and cracking down on them is seen as more problematic. Wilson further argues that one of the reasons why the government and the state institutions are unwilling or unable to prevent religious attacks is because of its" onand off" alliances with the Islamists. During the dictatorship under Suharto from 1966 to 1998, referred to as the new order period, the state had monopoly on violence. The state apparatus was working as a patron for the different vigilant groups, and used them as "assistants" for "regime maintenance". There was little room for violence which was not sanctioned by the state. According to Wilson, as a consequence of democratization and decentralization in 1998, a privatization of violence has been occurring in the post new order. Different vigilant groups are able to operate relatively freely as they have found other patrons/clients than the state (Wilson, 2005).

Wilson (2005) argues that the post new order period can be characterized as partial patronage. Sometimes vigilant groups make alliances with politicians, military, the police and the business elite, but these alliances are only temporary. This partial patronage has been beneficial for the fragmented political elite to gain economic or political power. He further argues that these groups have been used by the military and political elite to intimidate more progressive political and social elements of society. A Wikileaks report confirmed that also the police enjoyed close connections with Islamists (Jakarta Globe, 2011).

The police used the FPI as a tool, which would exempt them from criticism from human rights violations. However, these connections were also beneficial for the vigilant groups. Wilson argues that the temporary patronage has allowed the vigilant groups to operate with a certain degree of impunity and gain political leverage for controversial agendas.Yenny Wahid, the daughter of former President Abdurrahman Wahid (Gus Dur) stated even more strongly that the security forces that had helped form and finance FPI had created a monster that worked completely independently. Anyone could hire FPI for political purposes, but no one can control the leader Habib Rizieq (Jakarta Globe, 2012).

Since the state is so weak and fragmented, other actors have thus also sought control over the legitimate use of violence. Moreover, since some political and economic elites see the vigilant groups as a beneficial and extremely useful tool for political opportunism they are reluctant to crackdown on the vigilant groups. We can see these close connections in the case of West Java which will be described in more detail in the next section.

\section{The Importance of Local Politics: The Case of West Java}

This section uses on the case of West Java to illustrate how laws/decrees and political patronage as previously discussed, contribute to the legitimization of violence against the Ahmadiyah community. Hence, it is worth to mention that the case of West Java is the hotspot for violence against the Ahmadiyah community. In other provinces the police and the government have been more successful in preventing violence against the Ahmadiyah community. In 2011 three members of the Ahmadiyah community were beaten to death by a mob of about 1000 people in Cikeusik village. Only12 men were punished, viz. a lenient punishment of about three to six months.More importantly, one of the victims, an Ahmadiyah was also sentenced to jail for provoking the attacks and disturbing public order. He received the same punishment as the men who had killed the Ahmadiyyas. Police inspector Hasanuddin testified in the court, and emphasized that it was the Ahmadiyah as themselves who provoked the deadly killings by refusing to leave the house 
where they had been gathered (Human Right Reports, 2013). There have since then been several attacks on the Ahmadiyas and mosques in West Java.

After the transition to democracy in 1998, Indonesia has become increasingly decentralized, thus transferring power from the central government to the local governments. Decentralization was seen as a positive step in the sense that devolution of power was delegated to impoverished provinces outside the economic and political hub of Jakarta. However, it is claimed that decentralization has had a deteriorating effect on religious minorities, especially in West Java (Human Rights Reports, 2013).

\section{Laws and Decrees}

"The Joint Letter Ministerial Decree of 2008", which was a warning to the Ahmadiyahas, but not an outright ban, led to the encouragement of local governments and regencies to issue similar decrees in their respective provinces. For instance, Islamists pressured the mayor in Bekasi (which is the regency in West Java) Rahmat Effendi, to issue a similar anti-Ahmadiyah mayor regulation (Mayor regulation no.40, year, 2011 on "Banningahmadiyahactivities in Bekasi City"). Moreover, the mayor regulation has led Islamists to interpret the regulationas a complete ban on the Ahmadiyahs, and has pressured the regency to enforce the regulation. The recent occurrence in the Al Misbah mosque in Bekasi inWest Java illustrates this. The mosque has been sealed since April fifth, and at the time of writing there are still 18 people inside the mosque protesting against the sealingof the mosque. The closure prevents Ahmadiyahas from worshiping in the mosque. The sealing of the mosque was conducted by the mayor in Bekasi and local police officers. However, evidence suggests that the day before the sealing, FPI members came to the governmental office pressuring the government to enforce the mayor regulation or they would attack the mosque (Interview woth the Ahmadiyah leader in Bekasi). The fact that the mayor yielded to pressure from the FPI indicates that the group has some legitimacy. Most importantly, the mayorregulation gives the Islamists legitimating to pursue the Ahmadiyah community.

Ujang, the chairman of the Islamists group, Gempa, in West Java, emphasizes that the Islamists are just enforcing the laws. He says: "Religious violence occurred because the government failed to produce firm actions. The provincial government needs to demolish Ahmadiyah buildings in West Java province by using Governor Decree 2011, because the buildings violated provincial bylaws. In order to arrest the perpetrators, namely those who still defiantly do prayer in the sealed mosques, the police need to use Criminal Code Article 156a on religious blasphemy. So, this is clear. The chief problem is government performance in enforcement of law" (Interviews with Ujang, Chairman of Gempa).

Hence, laws and decrees seem to give added legitimacy for violence towards the Ahmadiyah community. This is in line with research conducted by the SETARA institute (2009) which confirms that violence towards the Ahmadiyah community has increased since the adoption of the different antiAhmadiyah decrees/regulations. There are some problems relating to the provincial/ mayor decrees. According to law 10 (3) 2004 (the law of the Republic of Indonesia Number 32, year 2004) concerning regional administration, religious affairs are within the jurisdiction of the central government, and not the local government. However, as in the case of West Java, different factors have contributed to religious freedom becoming a de facto local affair. For instance, another controversial decree is the highly controversial "Joint Ministerial Decree on the construction of houses of Worship 2006".

This decree requires permission from local authorities and consent from other religious communities to allow the building of houses of worship. This is problematic, since it should be a central government domain, but it also sets minority groups in 
a vulnerable position, because the building permissions depend on the consent of majority religious groups. Thus, through "the anti-Ahmadiyah regulations" and the "decree on houses of worship", religious affairs become de facto a local affair.

The Ahmadiyah community has now submitted a complaint to the court in Bandung. The Ahmadiyah leader Basit is suing the mayor for the closing of the mosque and for violating the joint ministerial decree of 2008. The court ruling will be important in determining religious freedom of the Ahmadiyah community in Bekasi, because a victory may force the local government to accommodate for minority groups. However, recent history illustrates that the regency in Bekasi has not always taken into consideration the rule of law and has gone beyond their power as regency. HKBP Filadelfia has been waiting for five years to gain permission to build a church in Bekasi district after submitting an application in 2007. The Supreme Court ruled that the HKBP Fildalefia should get a building permit to build a church. However, the court ruling has not been taken into consideration by the district administration, which still does not allow the building of a church (Ucanews.com, 2012). The fact that the central government has not intervened in any way to ensure worship permission for HKBP leaves the local government with enhanced powers which goes beyond their mandate.

Religious freedom should be a central government concern, but by ignoring local religious disputes, the State is legitimizing violence against the Ahmadiyah community or other minority groups. Moreover, the provincial anti-Ahmadiyah decrees have given the Islamists legitimization to pursue the Ahmadiyah community to enforce the decrees.

\section{Political Patronage}

The governor in West Java who belongs to the Prosperous Justice Party (PKS) has been criticized for being too lenient in preventing violence or infringement of religious freedom in West Java. It is speculated that the local governor in West Java enjoyed partial relations with the FPI and other radicals in West Java, and that they signed a deal agreeing on banning all the activities of the Ahmadiyahs in West Java. In return the hard liners would gather political support to the governor. Thus the Islamists seek political patronage from politicians who are willing to make alliances (Jakarta Globe, 2013).

The PKS is an Islamist Conservative Party, but it is argued that the connections with the FPI are more pragmatic than theological. West Java has a history of Islamism which is evident in the society today as well. Robin Bush argues that history and local culture play an important factor in determining local politics. West Java has a recent history of Islamism, where the Islamist secessionist movement "Darul Islam" first originated. The movement was critical to the new independent republic in the late 1940s, and promoted an Islamic state. Bush argues that these regions which supported an Islamist secessionist movement in the 1940s are also more positive to Islamist related laws such as Sharia by-laws (Bush, 2008). Drawing from this, one may argue that restrictive Ahmadiyah regulations may attract more voters in more "Islamist-oriented regions", such as west Java.

By-laws banning Ahmadiyahs or preventing them from worshipping are unconstitutional and should be the concern of the central government. Azyumardi Azra, a prominent Muslim scholar and director of the graduate school at the State Islamic University in Jakarta argues that the central government and President Yudhoyono do not have the political will to force the governors or the mayors to respect the different laws and court rulings in for instance Bekasi (The New Yorks Times, 2013). Bonar Tigor Naipospos, vice chairman from the Setara Institute argues that Mr. Yudhoyono has used the religious card to get political support from conservative Muslim groups and Islamist based political parties. Even though the President in principle has a commitment to plurality, his dependency on Islamist groups 
has made him reluctant to clamp down on religious attacks and discrimination. Thus, a harder crackdown on attacks on Ahmadiyah may lead to less political support and votes. Abuza argues however that politicians may have overestimated the Islamists strength, which is not as widespread as perceived. Most Muslims are moderate, while only a small percentage is considered Islamists (Abuza, 2007).

In summary, decentralization has had some unfortunate effects in Indonesia, in terms of religious freedom, especially in West Java. First of all, the different regencies are misusing laws and decrees to ban the Ahmadiyah community, which in turn encourages violent attacks by the Islamists. Moreover, alliances between the Islamists and the local political elite may give the Islamists impunity for their actions. A critical factor is that the central government is outright ignoring religious attacks and discrimination against the Ahmadiyah community in West Java. These factors contribute to the legitimatizing of violence against the Ahmadiyah community.

\section{The Islamists: Causes for Violence Theological Causes for Violence}

This section discusses on how the Islamists gain a certain degree of legitimacy in their use of violence. Indonesia is a predominantly Muslim society, with an 87, 2\% Muslim population. As mentioned most Muslims are moderate, with only $19 \%$ being referred to as Islamists. This group is diverse with different interests and priorities. Some belongs to political parties; some belongs to Islamist organizations and some to violent radical organizations such as the FPI (Weck, Noorhaidi, and Irfan, 2011). In this context, the Islamists' emphasis on the purification of Islam is of great significance. Their goal is to purify Islam from any impurities such as Western thought, and even worse- post- prophetic interpretations from the inside. Thus while many minority groups are targets of vigilant Islamist groups, the Ahmadiyah community is seen as extremely controversial. Not only do the religious teachings of the Ahmadiyahs deviate from the core teachings of Islam, but they nevertheless claim to be Muslims and they are thus seen to be attacking Islam from within. In the past few years, Indonesia has seen the rise of public condemnation of "Takfiri" (apostates and deviants). These condemnations have come in the form of fatwas from the quasi-official Ulamas Council of Indonesia (MUI). The fatwa states that the group is heretical and deviant. Abuza argues that while these fatwas do not have any legal bearing, they have been used as a justification for violent attacks (Abuza, 2007).

In an interview with Andi, the leader of an Islamist organization named Gapas, he confirmed the controversial nature of the Ahmadiyahs

When you mention whether the violent protest or religious violence was legitimate or not, we felt that our actions were legitimate. We told the Ahmadiyah people that if they claim to be Muslims, then they have to be the right Muslims. If they are not willing to implement Islamic tenets, don't use Islam as the name of their religion. Usually, they resisted our protests, and when that happened, we would fight back.

Hamdan from another Islamist organization called Pagar Akidah argued:

If the Ahmadiyah do not want to be attacked, do not want to be disturbed, they should establish their own religion. However, they claim to be Muslims, they claim their holy book is Al Quran, but they acknowledge additional verses. The prophet is not only Muhammad, but in addition to Muhammad, there is Mirza Ghulam Ahmad. We are really offended. If they name their religion other than Islam, the problem is over. In Islam, there is no religious sentiment. Ahmadiyah is established to destroy Islam from within. They are not able to overcome Islam when they meet Islam head to head, therefore they strike from within. We consider them non-Muslims who wish to destroy Islam from within.

Hence, it is evident that the Ahmadiyahs are controversial from a theological point of view. However, theological reasons may also 
work as a shield for secular reasons, as we will see in the next section.

\section{Theological Reasons May Work as a Shield for Secular Reasons}

There have been numerous articles about the theological and legal reasons for the attacks against the Ahmadiyah community. However, there has been limited research on secular or economic factors for the attacks. Wilson argues that criminal acts by Islamists may seem more legitimate when the motives are religious. Since the Ahmadiyah community in general is quite controversial, attacking Ahmadiyahas or infringing their religious freedom may seem more legitimate when using religious rhetoric. He argues that the characteristics of the Reformarsi Period are that criminal gangs or "premans" have essentially just changed into religious suits or clothes. In order to legitimize their actions they use religious symbols and religious rhetoric to shield secular reasons.

In an interview with the Ahmadiyah leader in Bekasi, Rahmat Rahmaijaya argued that the attacks and discrimination against the Ahmadiyah community may be secular as well as theological. The Ahmadiyah community in most areas of Indonesia tends to be wealthier or have a higher economic income than the rest of the population. Unlike other Muslim organizations the Ahmadiyah community does not get any funding from the government, but is still able to sustain itself. Indonesia has in the recent years experienced economic growth. However, economic growth has been coupled with inequality. Unemployment and poverty among the general population is evident in Indonesia. The relative deprivation theory is originally a social psychological theory, but has been developed in other social science disciplines to explain discrimination and violence towards groups (Pettigrew et al., 2008). This theory suggests that not poverty as such, but inequality can foster prejudice, discrimination and violence. The theory focuses on the feeling of deprivation due to economic comparisons with others. An individual or a group may feel deprived, when one feels worse off than its reference group in terms of economic income. Research indicates that it is particularly the collective aspect of deprivation which may lead to violence against the reference group (Pettigrew et al., 2008). In the case of the Ahmadiyah, violence may be a powerful motivator to reduce one's feeling of economic deprivation. Hence economic deprivation or jealousy among the low-ranking members of the Islamist organizations, may serve as a reason for the attacks on the more affluent Ahmadiyah community. In an interview conducted with the Lahore community (GAI) in Yogyakarta they emphasized the economic dimension as a cause for violence.

JAI is a big organization, receiving oversea funding, and is economically successful. They are also very exclusivist in the sense that they have their own mosque, they allow other Muslims in their mosque, but they only allow the Ahmadiyah themselves to manage their own mosque. Other exclusivist practices include only marrying Ahmadiyahs, and living in exclusivist areas such as Manislor in West Java.

Andi, the chairman of the Islamist group, Gapas, also stressed this and argued in the following way:

The second source of dispute is coming from within Ahmadiyah itself. They live by themselves. They don't want to mingle with other communities. When Muslims would like to pray in their mosques, they don't allow the Muslims to pray there. If the Muslims under certain circumstances are allowed to pray inside the mosques, the spot where Muslims conducted prayer is quickly cleaned up shortly after the prayer was done. So, they live by themselves. They maintain their exclusivity.

The JAI community, however, argues that this perception is false and that they do not wish to remain exclusivist, but policies and attacks by the government and the Islamist make them isolated from the rest of the population. Whether or not the exclusivist practice is voluntary or not, it does create a 
situation where the Ahmadiyah community is segregated from the rest of the society.

A researcher on religious violence argues that the Ahmadiyah community can be compared with the Mormons in the United States or the Jews prior to Second World War. The Mormons are perceived as controversial both from a theological and socio-economic perspective. They are also exclusivist and somewhat segregated, but economically powerful. They have also been victims of discriminatory practices in the United States. The Jews were perceived as wealthy, and were being labeled scapegoats for poverty and high unemployment in Europe. Even though the violence committed against the Jews was of a much bigger dimension, there are similarities in terms of religious minority status and economic prosperity (Interview with a PhD candidate on religious who wishes to remain anonymous).

As discussed above, there may be secular reasons for attacking the Ahmadiyahs, but there may also be secular reasons for joining Islamist groups. Sudirman Nasir argues that even though it is important to ensure efficient laws and law enforcement mechanisms, it is also extremely important to ensure employment and education opportunities for youth in Indonesia (Nasir, 2010). Research indicates that unemployment makes it more likely for youth to join radical violent organizations, because there are many nonmaterial and material benefits joining an organization. First of all, material benefits can come in terms of money, food et cetera. Hence some might join Islamist organizations such as the FPI to get access to these goods.

Nasir further argues that being unemployed may lead to a feeling of a loss of identity and loss of masculinity. Joining radical groups such as the FPI and other vigilant groups may in a non- conventional way give them a sense of belonging, a feeling of identity and increases their feeling of masculinity. Creating job and education opportunities may therefore be an important factor in combating violence against the
Ahmadiyah community. Thus, it is important to view the Ahmadiyah question holistically in order to find solutions to protect the Ahmadiyah community. Laws and law enforcement that protect the Ahmadiyah community is essential. Moreover, in order to reduce recruitment to Islamist organizations it is crucial to ensure social and economic rights. Hence, such efforts may reduce violence towards the Ahmadiyah despite theological disagreements among conventional Muslims.

\section{CONCLUSION}

Indonesia has a reputation for being a pluralistic nation promoting religious tolerance. Recently the President received a statesman award for promoting religious tolerance and pluralism in Indonesia. The award has however received massive criticism by human rights organizations. Indonesia is facing huge problems related to religious intolerance, especially towards religious minorities, and the government has not taken action against the violent vigilant groups. As a matter of fact, violence towards Ahmadiyahs is in danger of becoming legitimate.

As discussed in this article, the reason for violence towards the Ahmadiyah community is complex. The Indonesian state needs to regain its monopoly on violence, by ensuring security, justice and employment for the population as a whole. In that way, criminal gangs can no longer claim to act on behalf of a fragile and weak state. Increasing inequality and poverty is one of the major challenges facing Indonesia today. Creating job and working opportunities for Indonesians are extremely important in order to decrease recruitments to Islamist organization. These organizations are extremely attractive to unemployed youth, who use these organizations to recreate a sense of manhood and identity. Efficient laws and law- enforcement combined with economic and social reform is essential in preventing attacks and discrimination against the Ahmadiyah community. 


\section{BIBLIOGRAPHY}

Abubakar, I. Weck, W. Hasan, N. 2011. Islam in the Public Sphere, The politics of Identity and the Future of Democracy in Indonesia. Yogyakarta: CRCS

Abuza, Z. 2007. Political Islam and Violence in Indonesia: Asia Security Studies. New York: Routledge

Bamualim, S.Ch. 2011. Islamic Militancy and Resentment against Hadhramis in PostSuharto Indonesia: A Case Study of Habib Rizieq Syihab and His Islamic Islamic Defenders Front in Comparative Studies of South Asia, Africa and the Middle East. Volume 31, Number 2. Durham: Duke University Press.

Bush, R. 2008. Regional Sharia Regulations in Indonesia: Anomaly or Symptom? In Expressing Islam: Religious Life and Politics in Indonesia by Greg Fealy and Sally White (eds.). Singapore: Institute of Southeast Asian Studies

Colbran, N. 2010. "Realities and challenges in realizing freedom of religion or belief in Indonesia." Oslo: The International Journal of Human Rights, Vol. 14, No 5.

General Comment's no. 22. The Right to Freedom of Thought, Conscience and Religion

Indonesian Blashemy Law of 1965, Law of the Republic of Indonesia Number 1/PNS the year 1965, Jakarta January 27, 1965

Indonesian Human Right Act, Legislation Number 39, Year 1999 Concerning Human Rights, Jakarta September 23, 1999.

Indonesian Law No.32/2004, Law of the Republic of Indonesia Number 32, Year 2004 Concerning Regional Administration, Jakarta October 15, MPR: 2004

Indonesian MPR Decree of 2000 on the Source of LAW and Hierarchy of Laws, Jakarta, MPR
Indonesian Penal Code, The penal Code of the Republic of Indonesia, Jakarta 27, 1952

Joint Decree of the Minister of Religious Affairs, the Attorney General and the Minister of the Interior of the Republic of Indonesia. Jakarta, 2008

Mayor regulation no. 40, year, 2011 on "Banning ahmadiyah activities in Bekasi City".

International Covenant on Civil and Political Rights (ICCPR) Adopted by the United Nations General Assembly on 16 December, 1966

Olivier, R. 2004. Globalised Islam: The Search for a New Ummah. London: Hurst and Company

Pettigrew, T.F; Oliver, Ch; Roel, W.M; Rolf V.D.; and Andreas Zick. 2008. "Relative deprivation and Intergroup Prejudice." Malden: Journal of Social Issues. 64: 385-401

Setara Institute. 2009. Siding and Acting Intolerantly: Intolerance by Society and Restriction by the State in Freedom of religion/belief in Indonesia, Jakarta: SETARA Institute

The 1945 Indonesian Constitution

Tilly, C. 1985. "War making and state making as organized crime," in Bringing the state back, Peter R. Evans, Dietrich Ruesdchemeyer, and ThedaSkocpol (eds.). London: Cambridge University Press.

Tomte, A. 2012. "Constitutional review of the Indonesian Blasphemy Law." Oslo: Nordic Journal of Human Rights, Vol.30, No 2.

Weber, M. 1946. Essays in Sociology. New York: Oxford University Press.

Wilson, I.D. 2005. "Continuity and Change: The Changing Contours of Organized violence in Post-New Order Indonesia." Critical Asian Studies, 38 (2) 265-297. 


\section{INTERVIEWS}

Interview with the Ahmadiyah leader Rahmat Rahmaijayain Bekasi conducted on 13.06.2013

Interview with Andi, leader of the Islamists vigilant group "Gapas" conducted on 10.5.2013

Interview with Hamdan, leader of the Islamist group "Pagar Akidah" conducted on 10.05.2013

Interview with Ujang, the Chairman of the Islamist group "Gempa" conducted on 10.05.2013

Interview with a PhD candidate on religious violence who wishes to remain anonymous conducted on 07.01.2013

Interview with the Lahore Community (GAI) in Yogyakarta conducted on 06.07.2013

Interview with JAI in Yogyakarta conducted on 07.07.2013

\section{WEBSITES}

http:/ / www.thejakartaglobe.com/archive/ indonesian-police-used-fpi-as- attack-dog-leaked-us-cable-alleges / (Visited 1.5.2013)

http://www.ucanews.com/news/churchattacked-with-stones-urine-pastorsays/ 49933 (visited 25.5.2013)

http:/ / www.thejakartaglobe.com/archive/ west-java-governor-signs-deal-withfpi-banning-ahmadiyah(visited 23.5.2013)

http:/ / www.nytimes.com/2013/06/18/ world/asia/touting-islamto-draw-votes-in-indonesia. $\mathrm{html}$ ?pagewanted=all\&_r=0 (visited 20.1.2013)

www.jakartapost.com/nasir-sudirman-fpiand-low-income-youths(visited 10.05.2013)

http://www.nytimes.com/2011/05/20/ world/asia/20iht-indonesia20. html?pagewanted=all\&_r=0 (visited 3.4.2013)

http:/ / www.hrw.org/sites/default/ files/reports/indonesia0213 ForUpload_0.pdf, Human Rights Watch (2013), In Religions name "Abuses against religious minorities in Indonesia". (visited 1.5.2013) 